\title{
MODELLING OF ABRASIVE WEAR OF NI-BASED SELF-FLUXING ALLOY COATINGS BY THE APPLICATION OF EXPERIMENTAL DESIGN
}

\author{
Sara Havrlisan, Katica Simunovic, Djordje Vukelic
}

Original scientific paper

In this paper resistance to abrasive wear is studied of the Ni-based self-fluxing alloy coatings deposited by flame spraying with fusion. The "dry sand/rubber wheel" test in accordance with the ASTM G65 norm, specifically B and C procedures is used. The experimental data are statistically processed by using analysis of variance, to investigate the influence of two input variables (type of coating: $\mathrm{NiCrBSi}$, NiBSi; spraying distance: smaller, greater) and their interaction on the output variable (volume loss). Data for investigation were obtained by the full factorial design with two, previously mentioned, factors at two levels with three replications. The analysis of variance of obtained experimental data after 100 revolutions of wheel has shown that type of coating, spraying distance as well as interaction between these factors are significant and affect abrasive wear. At 2000 revolutions of wheel it has been found that the type of coating is a significant factor while the spraying distance, the same as interaction between these factors, is of no significance to abrasive wear.

Keywords: abrasive wear; analysis of variance; experimental design; flame spraying with fusion; $\mathrm{NiBSi}$; $\mathrm{NiCrBSi}$

Modeliranje procesa abrazijskog trošenja slojeva na bazi nikla primjenom planiranih pokusa

Izvorni znanstveni članak U ovom radu ispitivana je otpornost na abrazijsko trošenje slojeva na bazi Ni, koji su naneseni postupkom plinskog naštrcavanja s utaljivanjem.Korišten je test "suhi pijesak/gumeni kotač" prema normi ASTM G65 i to prema B i C varijanti postupka. Dobiveni eksperimentalni podaci su statistički obrađeni primjenom analize varijance, s ciljem istraživanja utjecaja dvije ulazne varijable (vrsta sloja: NiCrBSi, NiBSi; udaljenost plamenika od uzorka: manja, veća) te njihove interakcije na izlaznu varijablu (gubitak volumena). Podaci za istraživanje dobiveni su faktorskim planom pokusa s dva, prethodno navedena, faktora na dvije razine uz tri ponavljanja. Analizom varijance dobivenih eksperimentalnih podataka nakon 100 okretaja kotača utvrđeno je da su vrsta sloja, udaljenost plamenika od uzorka kao i interakcija između tih faktora značajni te da utječu na abrazijsko trošenje. Kod 2000 okretaja kotača utvrđeno je da je vrsta sloja značajan faktor tj. da promjena vrste sloja utječe na abrazijsko trošenje, dok udaljenost plamenika od uzorka kao i interakcija između tih faktora ne utječe na abrazijsko trošenje.

Ključne riječi: abrazijsko trošenje; analiza varijance; NiBSi; NiCrBSi; planirani pokus; plinsko naštrcavanje s utaljivanjem

\section{Introduction}

In order to prolong the service life of tribomechanical systems, thermal spraying is often applied to protect the new and repair the worn out machine parts. In this way the surfaces are obtained whose properties are much better than those of basic material. In thermal spraying procedures Ni-based self-fluxing alloys are widely represented. These alloys are known for their high strength and hardness and excellent resistance to wear, heat and corrosion. Due to the presence of $\mathrm{Cr}, \mathrm{B}, \mathrm{Si}$ and $\mathrm{C}$ hard phases are formed dispersed in the tough Ni matrix, thus providing good properties [1]. Nickel (Ni) provides ductility and resistance to corrosion, chromium $(\mathrm{Cr})$ is responsible for resistance to wear and corrosion, boron (B) decreases temperature of melting and improves resistance to wear, silicon $(\mathrm{Si})$ decreases temperature of melting and improves the properties of self fluxing, while carbon (C) makes formation of carbides possible, increasing hardness and resistance to wear of the coating $[2,3]$. In order to improve hardness of a coating and its resistance to abrasive wear, hard carbides $\mathrm{WC}$ and $\mathrm{TiC}$ are frequently added to Ni-based self-fluxing alloys $[3 \div 6]$. By addition of rare earth elements $\mathrm{CeO}_{2}$ and $\mathrm{La}_{2} \mathrm{O}_{3}$ toughness and resistance to wear and corrosion can be improved [7]. Due to their particularly good properties Ni-based self-fluxing alloys are used for repairs and improvement of components such as turbines, tools, rollers, extruders, plungers, piston rods, wearing plates and rolls for rolling mills whose surface is exposed to heavy wear [6]. In paper [8] the best combination of spraying procedure is studied (plasma arc welding, flame spraying and electric arc spraying) with regard to four types of coating (NiFeBSi-WC, NiCrBSiC, FeCrCTiSi, and $\mathrm{FeCrN}$ and $\mathrm{CSiBMn}$ ) aimed at acquiring the best resistance to wear of mill working parts.

The Ni-based self-fluxing alloys are particularly suitable for all types of thermal spraying: HVOF [2,

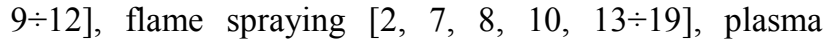
spraying $[3,10,11,16]$, plasma transferred arc welding $[5,8,20,21]$, laser cladding $[6,13,15]$ and arc welding $[4,8,22]$. So as to obtain the best properties of the sprayed coating, various combinations of the mentioned types of spraying as well as influence of particular alloying elements are investigated in the analysed papers. Investigations are conducted with regard to microstructures, mechanical properties, resistance to wear and corrosion [1, 23]. As already mentioned Ni-based self-fluxing alloys are applied in extreme wear conditions so as to prolong the service life of exposed parts, the way to direct or indirect reduction of tribomechanical systems' maintenance costs. That is why most authors deal with investigating resistance to wear (sliding wear, abrasive wear). When analysing sliding wear most often used tests are pin-on-disc, block-on-ring, ball-on-disk and ball-onflat tests. Abrasive wear is investigated by the application of tests according to different norms. Papers $[2,3,5]$ use "dry sand/rubber wheel" test according to ASTM G65-04 norm, abrasive test T-07 tester of rubber-wheel type is applied in paper [4], while pin-on-disc test according to ASTM G132 norm is applied in paper [8]. 
This paper is aimed at investigating the resistance of NiCrBSi and NiBSi coatings to abrasive wear acording to the ASTM G65 norm depending on the spraying distance during flame spraying with fusing.

\section{Experimental investigations}

Data for investigation are obtained by the full factorial design of experiment with two factors at two levels with three replications. Input variables i.e. parameters that varied at two levels are: type of coating (NiCrBSi and NiBSi) and spraying distance (small, great). Spraying distances from the sample during deposition are $6 \mathrm{~mm}$ (small) and $20 \mathrm{~mm}$ (great). As Eutalloy spraying is a manual technique and depends on the operator, due to the impossibility of monitoring the exact distance, it has been decided that the levels of the spraying distance factor will be marked as a small distance category and a great distance category. Repetition of each combination of the factor levels has been conducted three times. Therefore, the final number of experimental samples was 12 (four combinations of the levels of factors replicated three times). The output variable, i.e. response, is the volume loss due to abrasive wear, after 2000 and 100 revolutions of the wheel.

First, by flame spraying with fusion the NiCrBSi (Eutalloy 10009) and NiBSi (Eutalloy 10185) coatings were deposited on the substrate material, tool steel Utop Mo1, EN X27CrMoV51 whose chemical composition is shown in Tab. 1. Chemical composition of the spraying powder is presented in Tab. 2 while technical data of the powder are given in Tab. 3 .

Table 1 Chemical composition of the substrate material, EN X27CrMoV51

\begin{tabular}{|c|c|c|c|c|c|c|c|c|}
\hline Chemical element & $\mathrm{C}$ & $\mathrm{Si}$ & $\mathrm{Mn}$ & $\mathrm{P}$ & $\mathrm{S}$ & $\mathrm{Cr}$ & $\mathrm{Mo}$ & $\mathrm{V}$ \\
\hline wt. $/ \%$ & 0,38 & 0,94 & 0,39 & 0,020 & 0,0006 & 4,89 & 1,27 & 0,50 \\
\hline
\end{tabular}

Table 2 Chemical composition of the spraying powders

\begin{tabular}{|l|c|c|c|c|c|c|}
\hline \multicolumn{1}{|c|}{ Chemical element/ wt. / \% } & $\mathrm{C}$ & $\mathrm{Cr}$ & $\mathrm{Fe}$ & $\mathrm{B}$ & $\mathrm{Si}$ & $\mathrm{Ni}$ \\
\hline Eutalloy 10009, NiCrBSi & 0,7 & $\mathbf{1 5}$ & 3,5 & 3,2 & 4,4 & balance \\
\hline Eutalloy 10185, NiBSi & 0,1 & $\mathbf{0 , 5}$ & 0,5 & 2,5 & 3 \\
\hline
\end{tabular}

Table 3 Technical data of the spraying powders

\begin{tabular}{|l|c|c|}
\hline & $\begin{array}{c}\text { Eutalloy 10009 } \\
/ \mathrm{NiCrBSi}\end{array}$ & $\begin{array}{c}\text { Eutalloy } 10185 \\
/ \mathrm{NiBSi}\end{array}$ \\
\hline Melting range (sol./liq.) $/{ }^{\circ} \mathrm{C}$ & $965 \div 1210$ & $1050 \div 1175$ \\
\hline Hardness / HRC & $56 \div 62$ & $36 \div 42$ \\
\hline Specific gravity $/ \mathrm{g} / \mathrm{cm}^{3}$ & 7,82 & 7,88 \\
\hline Service temperature $/{ }^{\circ} \mathrm{C}$ & 700 & 600 \\
\hline
\end{tabular}

Shape and dimensions of the sample are displayed in Fig. 1. A groove was milled on the specimen so as to provide constant depth of the coating of all samples after finish machining operation.

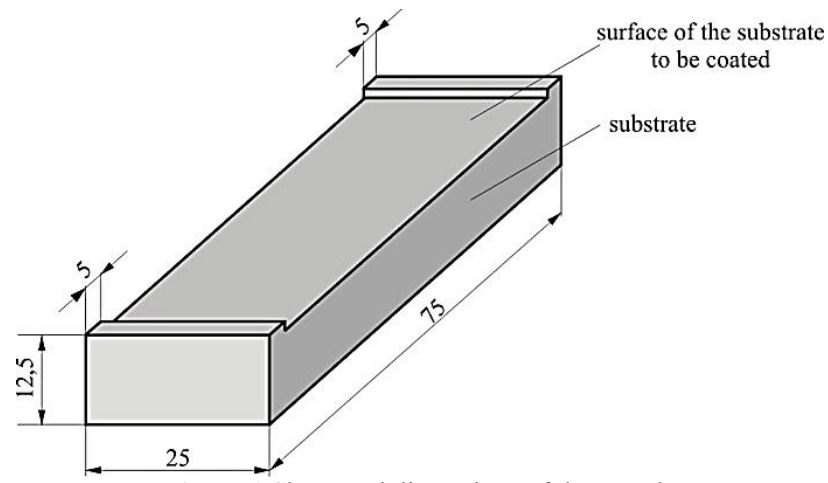

Figure 1 Shape and dimensions of the sample

Previous to spraying the surface to be sprayed must be prepared so as to provide the best adhesion of the sprayed coating. Several steps are included into the substrate preparation:

- $\quad$ substrate degreasing,

- substrate deroughening by grinding,

- $\quad$ substrate heating to $200{ }^{\circ} \mathrm{C}$.

Fig. 2 shows the procedure of flame spraying with fusing by SuperJet-Eutalloy oxy-acetylene torch, where the mixture of gases (acetylene pressure $50 \mathrm{kPa}$ and oxygen pressure $200 \mathrm{kPa}$ ) and powder is mixed within the torch and leaves the torch nozzle of size B3 in the form of flame, simultaneously fused with the substrate. Metallurgical bond is thus provided between the substrate and the coating. In order to provide corresponding thickness of the coating, the coating is deposited through eight layers.

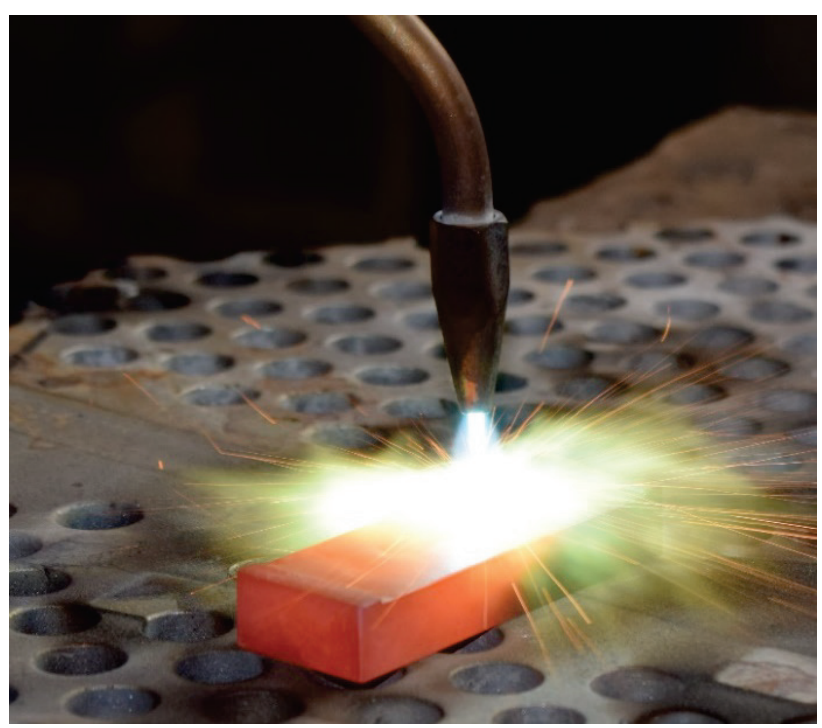

Figure 2 Procedure of flame spraying with fusion

\subsection{Analysis of resistance to abrasive wear}

After spraying the samples were ground so as to obtain a smooth surface with $1 \mathrm{~mm}$ thick sprayed coating.

Analysis of resistance to abrasive wear was conducted in accordance with the design of experiment shown in Tab. 4. 
Table 4 Experimental details for the "dry sand/rubber wheel" testing

\begin{tabular}{|c|c|c|}
\hline $\begin{array}{c}\text { Coating/Spraying } \\
\text { distance }\end{array}$ & Sample designation & Testing parameters \\
\hline NiCrBSi coating/ & 111 & Procedure B (force \\
Small spraying & 112 & against specimen \\
distance & 113 & 130 N; the number \\
of wheel \\
NiCrBSi coating/ & 121 & revolutions 2000) \\
Great spraying & 122 & Procedure C \\
distance & 123 & (force against \\
\cline { 1 - 2 } NiBSi coating/ & 211 & thecimen $130 \mathrm{~N}$; \\
Small spraying & 212 & wheel revolutions \\
distance & 213 & 100) \\
\hline NiBSi coating/ & 221 & \\
Great spraying & 222 & \\
distance & 223 &
\end{tabular}

To analyse the resistance to abrasive wear the test "dry sand/rubber wheel" was used according to the ASTM G65 norm [24]. The analysis consists of abrading a standard sample of dimensions $75 \times 25 \times 12,5 \mathrm{~mm}$ by quartz sand Ottawa AFS 50/70 (Fig. 3).

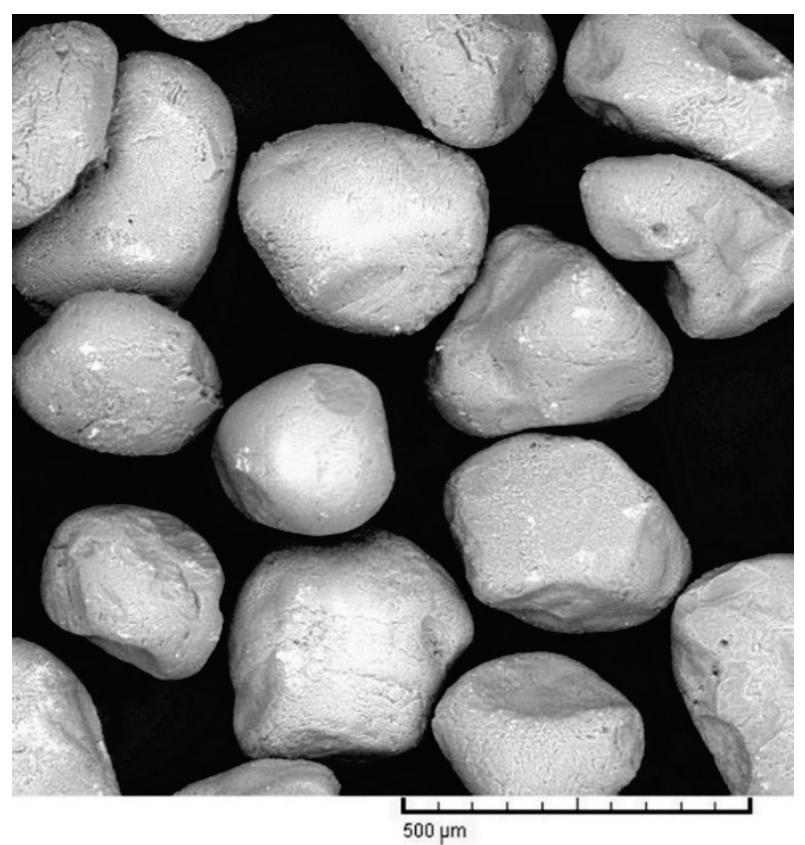

Figure 3 Quartz sand Ottawa AFS50/70

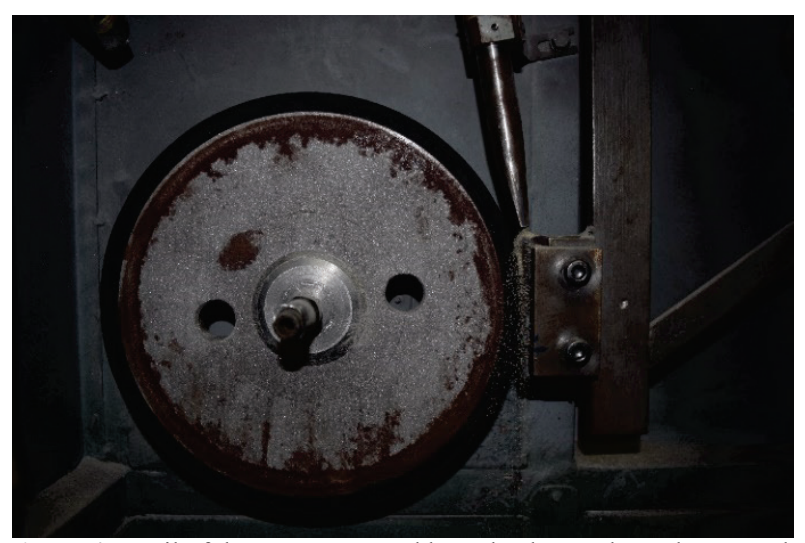

Figure 4 Detail of the apparatus - rubber wheel - sand nozzle - sample

Sand flows through the nozzle and is supplied between the sample and rotating wheel lined with rubber of hardness 60 Shore A (Fig. 4). Depending on the variant used in the process (Fig. 5) a corresponding force acts on the sample through the lever arm.

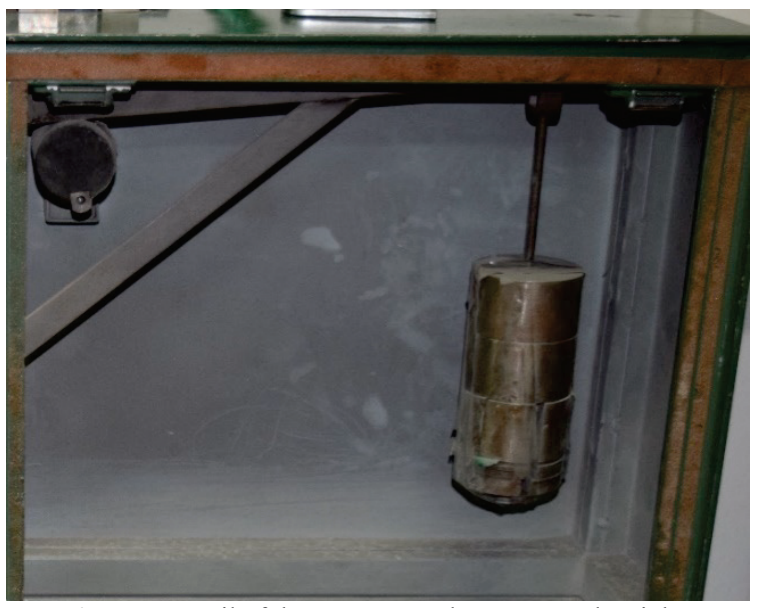

Figure 5 Detail of the apparatus - lever arm and weights

Resistance to abrasive wear is studied according to the $\mathrm{B}$ and $\mathrm{C}$ variants of the procedure (Tab. 5). Procedures $\mathrm{B}$ and $\mathrm{C}$ are short-term variants of Procedure A which is used to rank the materials of medium to high abrasion resistance [24].

Table 5 Variants of the procedure according to ASTM G65 [24]

\begin{tabular}{|l|c|c|}
\hline \multicolumn{1}{|c|}{ Variants of the procedure } & $\mathrm{B}$ & $\mathrm{C}$ \\
\hline Force against specimen, $\mathrm{N}$ & 130 & 130 \\
\hline Wheel revolutions & 2000 & 100 \\
\hline Relative path, $\mathrm{m}$ & 1436 & 71,8 \\
\hline Duration tests, $\mathrm{min}$ & 10 & 0,5 \\
\hline
\end{tabular}

The samples were weighed on analytic scales METLLER B5C 1000, precision $10^{-4} \mathrm{~g}$ (Fig. 6) and their mass loss was determined by weighing them before and after the analysis.

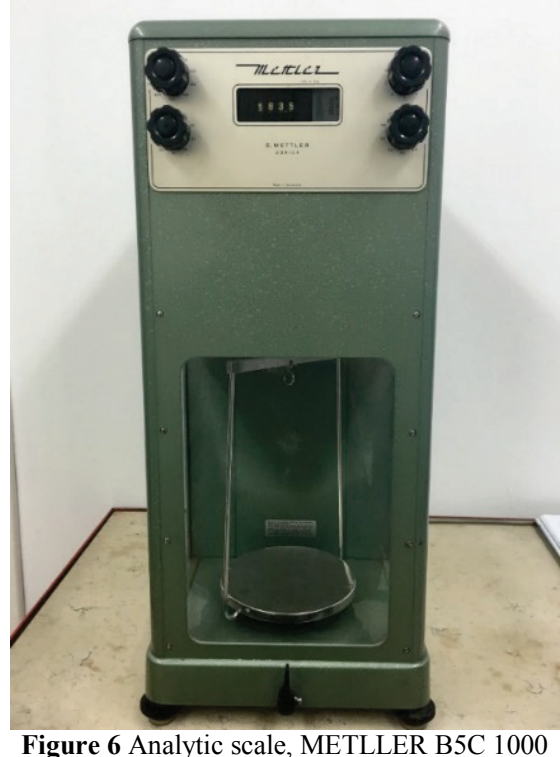

According to the ASTM G65 norm the mass loss is converted into the volume loss, Eq. (1).

$$
\Delta V=\frac{\Delta m}{\rho} \cdot 1000
$$

where is $\Delta V$ - volume loss $\left(\mathrm{mm}^{3}\right), \Delta m$ - mass loss $(\mathrm{g})$ and $\rho$-density $\left(\mathrm{g} / \mathrm{cm}^{3}\right)$. 
Fig. 7 shows parallel marks of wear for all four combinations of factors, specifically after 2000 and after 100 revolutions.

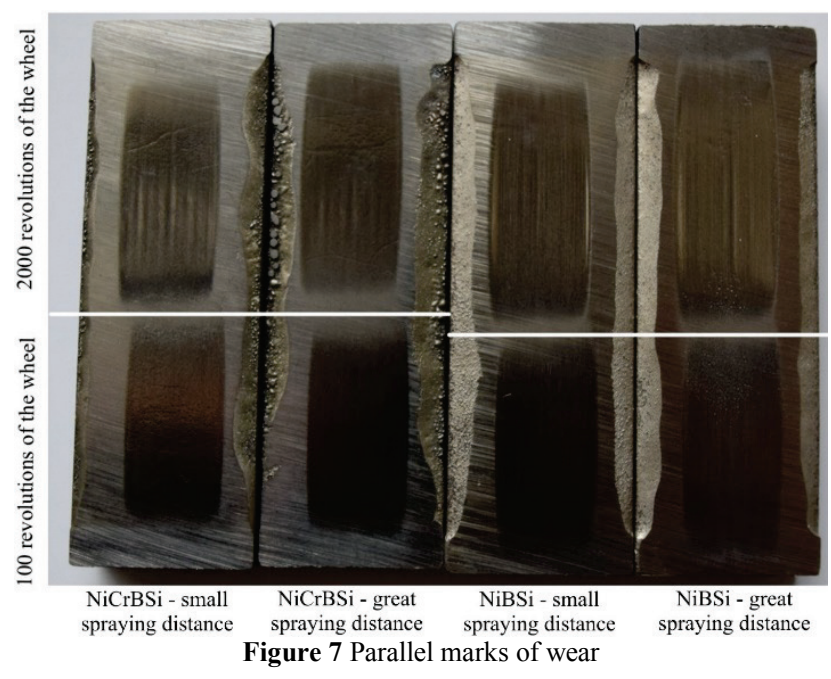

\section{Results and discussion}

For statistical analysis of the measured response volume loss (Tabs. 6 and 8), order of execution of experiments and analysis of variance, licenced software Design Expert (version DX10, 10.0.3.1, Stat-Ease, Inc. Minneapolis, 2016) was used. Influence of a particular factor on output variable, the same as interaction of these factors, were investigated by the analysis of variance of experimental data.

Order of execution of the experiment (Run), taking into consideration the principle of randomization, and obtained results, are displayed in Tab. 6. The last column represents the output variable - volume loss due to abrasive wear after 2000 revolutions of the wheel.
Table 6 Design of experiments and results of the abrasive wear after 2000 revolutions of the wheel

\begin{tabular}{|c|c|c|c|c|}
\hline Std & Run & $\begin{array}{c}\text { Factor 1 } \\
\text { A: Type of } \\
\text { coatings }\end{array}$ & $\begin{array}{c}\text { Factor 2 } \\
\text { B: Spraying } \\
\text { distance }\end{array}$ & $\begin{array}{c}\text { Response } \\
\text { Volume loss, } \\
\mathrm{mm}^{3}\end{array}$ \\
\hline 8 & 1 & $\mathrm{NiCrBSi}$ & great & 3,0307 \\
\hline 2 & 2 & $\mathrm{NiCrBSi}$ & small & 4,0921 \\
\hline 5 & 3 & $\mathrm{NiBSi}$ & small & 27,6650 \\
\hline 7 & 4 & $\mathrm{NiCrBSi}$ & great & 3,9898 \\
\hline 12 & 5 & $\mathrm{NiBSi}$ & great & 25,4315 \\
\hline 3 & 6 & $\mathrm{NiCrBSi}$ & small & 3,4527 \\
\hline 10 & 7 & $\mathrm{NiBSi}$ & great & 22,3858 \\
\hline 9 & 8 & $\mathrm{NiCrBSi}$ & great & 3,6317 \\
\hline 4 & 9 & $\mathrm{NiBSi}$ & small & 24,7462 \\
\hline 1 & 10 & $\mathrm{NiCrBSi}$ & small & 3,9642 \\
\hline 6 & 11 & $\mathrm{NiBSi}$ & small & 24,2131 \\
\hline 11 & 12 & $\mathrm{NiBSi}$ & great & 22,8807 \\
\hline
\end{tabular}

Tab. 7 displays the statistical parameters for 12 tested samples - abrasive wear after 2000 revolutions of the wheel.

Table 7 Some statistical parameters after 2000 revolutions of the wheel

\begin{tabular}{|l|r|}
\hline Minimum volume loss $/ \mathrm{mm}^{3}$ & 3,0307 \\
\hline Maximum volume loss $/ \mathrm{mm}^{3}$ & 27,6650 \\
\hline Mean volume loss $/ \mathrm{mm}^{3}$ & 14,1236 \\
\hline Standard deviation volume loss $/ \mathrm{mm}^{3}$ & 10,9725 \\
\hline
\end{tabular}

Analysis of variance for the volume loss due to abrasive wear after 2000 revolutions of the wheel is shown in Tab. 8.

It is visible from Tab. 8 that $F$ value of the model is 270,14 which implies that the model is significant. There is only $0,01 \%$ probability that value $F$ is that high due to noise. It is visible that the type of coating is a significant factor. For the type of coating factor, $p$ value for the variable $F$ value $(806,74)$ is less than the probability of error type I 0,05 .

Table 8 Analysis of variance for the model - ASTM Procedure B - 2000 wheel revolutions

\begin{tabular}{|l|c|c|c|c|}
\hline \multicolumn{1}{|c|}{ Source } & Sum of squares & Degrees of freedom & Mean square & $\begin{array}{c}p \text {-value } \\
\text { Prob }>F\end{array}$ \\
\hline Model value & 3 & 437,14 & 270,14 \\
\hline A-type of coating & 1311,42 & 1 & 1305,44 & 806,74 \\
\hline B-spraying distance & 1305,44 & 1 & 3,83 & 2,37 \\
\hline Interaction AB & 3,83 & 1 & 2,14 & 0,0001 \\
\hline Pure Error & 2,14 & 8 & 1,62 & 0,1623 \\
\hline Corrected Total & 12,95 & 11 & & \\
\hline
\end{tabular}

It can be concluded that the type of coating is a significant factor and that the change of the type of coating affects the volume loss due to abrasive wear, while the spraying distance as well as the interaction of these factors have no influence on the volume loss due to abrasive wear after 2000 revolutions.

Graphic representation of results obtained by experiment - volume loss in dependence on type of coating and spraying distance is shown in Fig. 8. It is visible from the figure that depending on the spraying distance the NiCrBSi coating has a smaller volume loss due to abrasive wear after 2000 revolutions of the wheel in relation to the $\mathrm{NiBSi}$ coating, i.e. that it has better abrasive resistance. Little dots in the graphic representation represent the predicted values of the volume loss.
The obtained data resulted in regression model with coded values of the factors (Eq. (2)), the coded levels for factor $A$ (coating type) being -1 (NiCrBSi) and +1 (NiBSi), and for factor $B$ (spraying distance) -1 (small) and +1 (great). The coefficient of determination $R^{2}$ is 0,9902 .

$\Delta V_{2000}=14,12+10,43 \cdot A-0,57 \cdot B-0,42 \cdot A \cdot B$ 


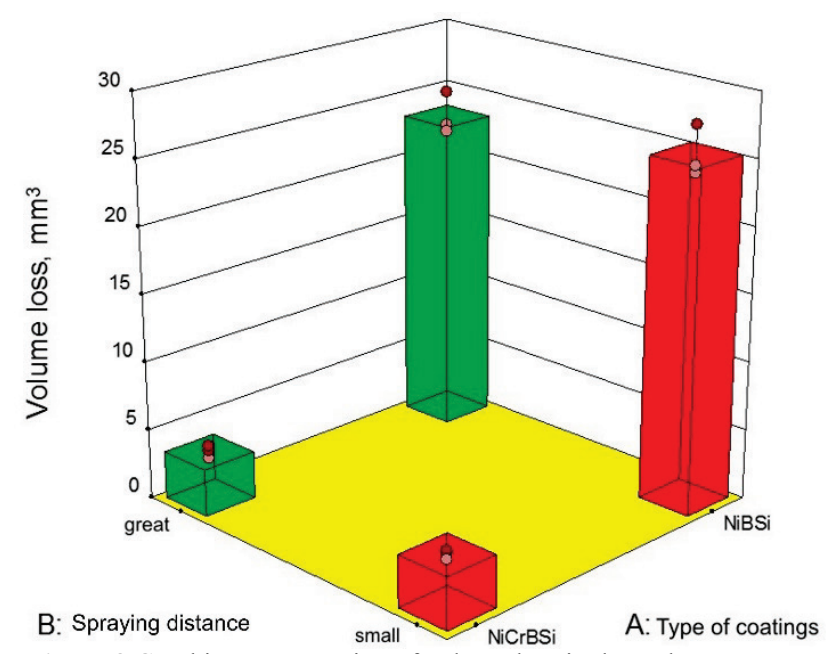

Figure 8 Graphic representation of volume loss in dependence on type of coatings and spraying distance after 2000 revolutions of the wheel

Fig. 9 gives graphic representation of comparison of real values i.e. data obtained by experiment and predicted values. For the NiCrBSi coating, depending on the spraying distance, there is little departure between the data obtained by experiment (actual) and the predicted data, while for the NiBSi coating, depending on the spraying distance, the departures are somewhat bigger.

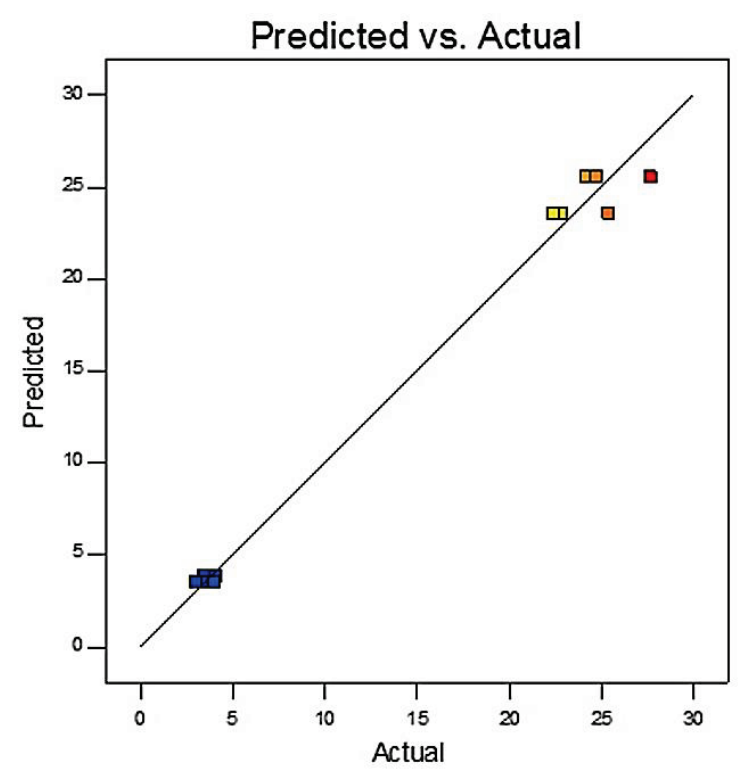

Figure 9 Graphical representation of comparison of actual data i.e. data obtained by experiment and predicted values of abrasive wear after 2000 revolutions of the wheel
The order in which the experiment with 100 revolutions of wheel was performed considering the principle of randomization, and the obtained results, is demonstrated in Tab. 9. The last column represents the output variable - volume loss due to abrasive wear after 100 revolutions of the wheel.

Table 9 Design of experiments and results of the abrasive wear after 100 revolutions of the wheel

\begin{tabular}{|c|c|c|c|c|}
\hline Std & Run & $\begin{array}{c}\text { Factor 1 } \\
\text { A: Type of } \\
\text { coatings }\end{array}$ & $\begin{array}{c}\text { Factor 2 } \\
\text { B: Spraying } \\
\text { distance }\end{array}$ & $\begin{array}{c}\text { Response } \\
\text { Volume loss, } \\
\mathrm{mm}^{3}\end{array}$ \\
\hline 3 & 1 & NiCrBSi & small & 0,6394 \\
\hline 10 & 2 & NiBSi & great & 1,7513 \\
\hline 7 & 3 & NiCrBSi & great & 0,5115 \\
\hline 4 & 4 & NiBSi & small & 2,1574 \\
\hline 11 & 5 & $\mathrm{NiBSi}$ & great & 1,7386 \\
\hline 1 & 6 & $\mathrm{NiCrBSi}$ & small & 0,5882 \\
\hline 12 & 7 & $\mathrm{NiBSi}$ & great & 1,8528 \\
\hline 8 & 8 & $\mathrm{NiCrBSi}$ & great & 0,4604 \\
\hline 5 & 9 & $\mathrm{NiBSi}$ & small & 2,3096 \\
\hline 2 & 10 & $\mathrm{NiCrBSi}$ & small & 0,4987 \\
\hline 6 & 11 & $\mathrm{NiBSi}$ & small & 2,4873 \\
\hline 9 & 12 & $\mathrm{NiCrBSi}$ & great & 0,3836 \\
\hline
\end{tabular}

Tab. 10 shows some statistical parameters for 12 test samples - abrasive wear after 100 revolutions of the wheel.

Table 10 Some statistical parameters after 100 revolutions of the wheel

\begin{tabular}{|l|r|}
\hline Minimum volume loss $/ \mathrm{mm}^{3}$ & 0,3836 \\
\hline Maximum volume loss $/ \mathrm{mm}^{3}$ & 2,4873 \\
\hline Mean volume loss $/ \mathrm{mm}^{3}$ & 1,2816 \\
\hline Standard deviation volume loss $/ \mathrm{mm}^{3}$ & 0,8319 \\
\hline
\end{tabular}

Analysis of variance for the volume loss due to abrasive wear after 100 revolutions of the wheel is shown in Tab. 11 .

It is visible from Tab. 11 that the $F$ value of the model is 248,32 which implies that the model is significant. There is only $0,01 \%$ probability that the $F$ value is so high because of noise. It can be seen that type of coating, spraying distance as well as interaction of those two factors are significant. For those factors, $p$ value for the $F$ variable value $(700,72 ; 32,43 ; 12,70)$ is less than the probability of error of type I 0,05 .

It can be concluded that the change of coating type, the spraying distance and the interaction of those two factors affect the volume loss due to abrasive wear after 100 revolutions of the wheel.

Table 11 Analysis of variance for the model - ASTM Procedure C - 100 wheel revolutions

\begin{tabular}{|l|c|c|c|c|c|}
\hline \multicolumn{1}{|c}{ Source } & Sum of squares & Degrees of freedom & Mean square & $\begin{array}{c}p \text {-value } \\
\text { Prob }>F\end{array}$ & \multicolumn{2}{c|}{\begin{tabular}{c} 
value \\
\hline Model
\end{tabular}} & 7,53 & 3 & 2,51 & 248,32 \\
\hline A-type of coating & 7,08 & 1 & 7,08 & 700,72 & 32,43 \\
\hline B-spraying distance & 0,33 & 1 & 0,33 & 0,001 \\
\hline Interaction AB & 0,13 & 1 & 0,13 & 0,0005 \\
\hline Pure Error & 0,081 & 8 & 0,01 & 0,0073 \\
\hline Corrected Total & 7,61 & 11 & & \\
\hline
\end{tabular}

Graphic representation of the results obtained by experiment - volume loss in dependence on type of coating and spraying distance are demonstrated in Fig. 10. The figure shows that depending on the spraying distance the NiCrBSi coating loses less volume due to abrasive wear after 100 revolutions of the wheel than the NiBSi coating i.e. it has better abrasive resistance. It can be seen from the diagram that the spraying distance influences 
abrasive wear of the NiBSi coating; the greater the spraying distance the less the abrasive wear. The effect of the spraying distance to abrasive wear is less pronounced with the NiCrBSi coating. Little dots in the graphic representation show the predicted values of the volume loss.

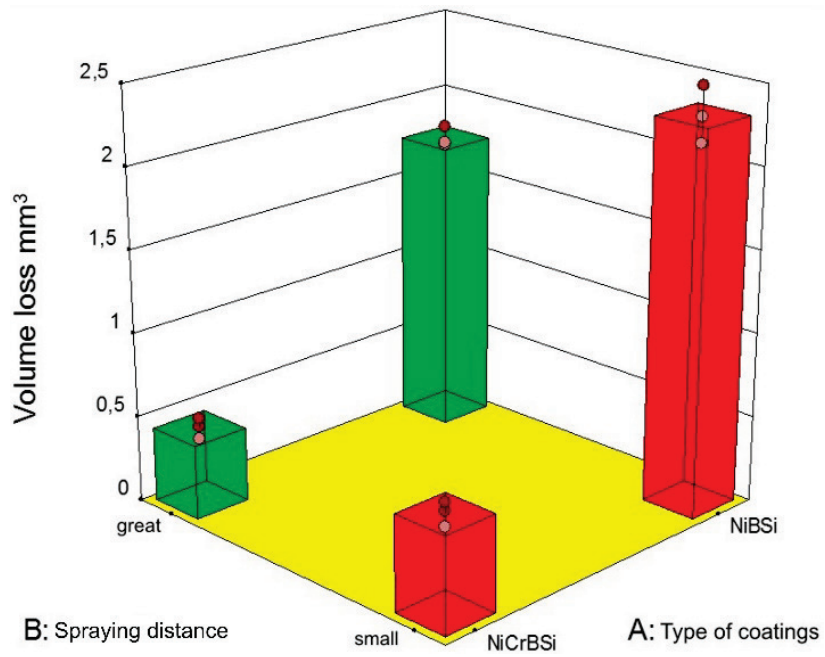

Figure 10 Graphic representation of volume loss in dependence on type of coatings and spraying distance after 100 revolutions of the wheel

Using the obtained data a regression model was obtained (Eq. (3)) with coded values of factors with coded levels for factor A (type of coating) -1 (NiCrBSi) and +1 (NiBSi), and for factor B (spraying distance) -1 (small) and +1 (great). The coefficient of determination $R^{2}$ is 0,9894 .

$\Delta V_{100}=1,28+0,77 \cdot A-0,17 \cdot B-0,1 \cdot A \cdot B(3)$

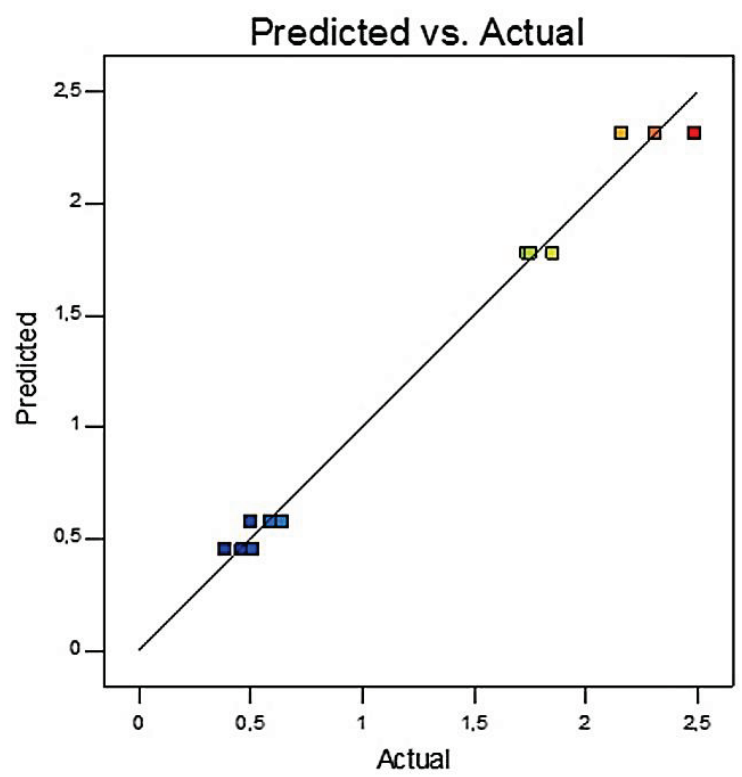

Figure 11 Graphical representation of comparison of actual data i.e. data obtained by experiment and predicted values of abrasive wear after 100 revolutions of the wheel

Fig. 11 is a graphical representation of comparison of real data i.e. data obtained by experiment and predicted values. For the NiCrBSi coating, depending on the spraying distance there is little departure of the data obtained by experiment and predicted values, while for the NiBSi coating the departure is somewhat bigger with small spraying distance.

\section{Conclusion}

In this paper the data for investigation were obtained by the factorial design of experiment with two factors (type of coating material and spraying distance) at two levels with three replications. The output variable is the volume loss due to abrasive wear after 2000 and 100 revolutions of the wheel.

By the analysis of variance of experimental data volume loss due to abrasive wear after 2000 revolutions, it has been found that the type of coating is the only factor of significance i.e. that the change of the type of coating affects abrasive wear. By the analysis of variance of experimental data - volume loss due to abrasive wear after 100 revolutions of wheel, it has been established that the type of coating, the spraying distance and the interaction of those two factors are significant.

This also shows that with both the first and the second number of revolutions of the wheel there is a difference in the volume losses for the smaller or greater spraying distance, but the difference is significant only for the smaller number of the wheel revolutions. Variability due to repetition is very important. It is quite insignificant when the number of the wheel revolutions is small (it amounts to only 0,01 , see Tab. 11) i.e. the data are more equalized for all three samples in each combination of the levels of factors, and the reason for this could be found in the short lasting of wear. When the number of revolutions of the wheel is smaller, which is also a process of short duration, the surface layer of the coating only is being worn out while with a greater number of the wheel revolutions the coating wear is deeper. In order to investigate in more detail the effect of spraying distance on abrasive wear and make more concrete conclusions, further investigations are proposed aimed at investigating the coating microstructure, measuring the coating microhardness and hardness.

\section{Acknowledgements}

This research is accomplished within the projects Nos. IZIP-2014-95 and INGI-2015-28 financed by the Josip JurajStrossmayer University of Osijek.

\section{References}

[1] Simunovic, K.; Saric, T.; Simunovic, G. Different Approaches to the Investigation and Testing of the NiBased Self-Fluxing Alloy Coatings-A Review. Part 1: General Facts, Wear and Corrosion Investigations. // Tribology Transactions. 57 (2014), pp. 255-279. DOI: 10.1080/10402004.2014.927547

[2] Houdkova, S.; Smazalova, E.; Vostrak, M.; Schubert, J. Properties of NiCrBSi coating, as sprayed and remelted by different technologies. // Surface \& Coatings Technology. 253 (2014), pp. 14-26. DOI: 10.1016/j.surfcoat.2014.05.009

[3] Natarajan, S.; Edward Anand, E.; Akhilesh, K. S.; Rajagopal, A.; Nambiar, P. P. Effect of graphite addition on the microstructure, hardness and abrasive wear behaviour of plasma sprayed NiCrBSi coatings. // Materials 
Chemistry and Physics. 175 (2016), pp. 100-106. DOI: 10.1016/j.matchemphys.2016.02.076

[4] Sheppard, P.; Koiprasert, H. Effect of W dissolution in NiCrBSi-WC and NiBSi-WC arc sprayed coatings on wear behaviors. // Wear. 317 (2014), pp. 194-200. DOI: 10.1016/j.wear.2014.06.008

[5] Liyanage, T.; Fisher, G.; Gerlich, A. P. Microstructure and abrasive wear performance of PTAW deposited Ni-WC overlays using different Ni-alloy chemistries. // Wear. 274275 (2012), pp. 345-354. DOI: 10.1016/j.wear.2011.10.001

[6] Guo, C.; Chen, J.; Zhou, J.; Zhao, J.; Wang, L.; Yu, Y.; Zhou, H. Effects of WC-Ni content on microstructure and wear resistance of laser cladding Ni-based alloys coating. // Surface \& Coatings Technology. 206 (2012), pp. 20642071. DOI: 10.1016/j.surfcoat.2011.06.005

[7] Sharma, S. P.; Dwivedi, D. K.; Jain, P. K. Effect of $\mathrm{La}_{2} \mathrm{O}_{3}$ addition on the microstructure, hardness and abrasive wear behaviour of flame sprayed Ni based coatings. // Wear. 267 (2009), pp. 853-859. DOI: 10.1016/j.wear.2008.12.029

[8] Vencl, A.; Katavic, B.; Markovic, D.; Ristic, M.; Gligorijevic, B.The Tribological Performance of Hardfaced / Thermal Sprayed Coatings for Increasing the Wear Resistance of Ventilation Mill Working Parts. // Tribology in Industry. 37, 3 (2015), pp. 320-329.

[9] Zhao, W. M.; Wang, Y.; Han, T.; Wu, K. Y.; Xue, J. Electrochemical evaluation of corrosion resistance of NiCrBSi coatings deposited by HVOF. // Surface \& Coatings Technology. 183 (2004), pp. 118-125. DOI: 10.1016/j.surfcoat.2003.09.053

[10] Planche, M. P.; Liao, H.; Normand, B.; Coddet, C. Relationships between NiCrBSi particle characteristics and corresponding coating properties using different thermal spraying processes. // Surface \& Coatings Technology. 200 (2005), pp. 2465-3473. DOI: 10.1016/j.surfcoat.2004.08.224

[11] Miguel, J. M.; Guilemany, J. M.; Vizcaino, S. Tribological study of NiCrBSi coating obtained by different processes. // Tribology International. 36 (2003), pp. 181-187. DOl: 10.1016/s0301-679x(02)00144-5

[12] Kekes, D.; Psyllaki, P.; Vardavoulias, M. Wear MicroMechanisms of Composite WC-Co/Cr $-\mathrm{NiCrFeBSiC}$ Coatings. Part I: Dray Sliding. Tribology in Industry. 36, 4 (2014), pp. 361-374.

[13] Gonzalez, R.; Garcia, M. A.; Penuelas, I.; del Rocio Fernandez, M.; Hernandez Battez, A.; Felgueroso, D. Microstructural study of NiCrBSi coatings obtained by different processes. // Wear. 263 (2007), pp. 619-624.DOI: 10.1016/j.wear.2007.01.094

[14] Hejwowski, T.; Szewczyk, S.; Weronski, A. An investigation of the abrasive and erosive wear of flamesprayed coatings. // Journal of Materials Processing Technology. 106 (2000), pp. 54-57. DOI: 10.1016/s09240136(00)00638-5

[15] Navas, C.; Colaco, R.; de Damborenea, J.; Vilar, R. Abrasive wear behaviour of laser clad and flame sprayedmelted NiCrBSi coatings. // Surface \& Coatings Technology. 200 (2006), pp. 6854-6862. DOI: 10.1016/j.surfcoat.2005.10.032

[16] Rodriguez, J.; Martin, A.; Fernandez, R.; Fernandez, J. E. An experimental study of the wear performance of NiCrBSithermal spray coatings. // Wear. 255 (2003), pp. 950-955. DOI: 10.1016/s0043-1648(03)00162-5

[17] Serres, N.; Hlawka, F.; Costil, S.; Langlade, C.; Machi, F. An investigation of the mechanical properties and wear resistance of NiCrBSi coatings carried out by in situlaser remelting. // Wear. 270 (2011), pp. 640-649. DOl: 10.1016/j.wear.2011.01.025

[18] Gonzales, R.; Cadenas, M.; Fernandez, R.; Cortizo, J. L.; Rodriguez, E. Wear behaviour of flame sprayed NiCrBSicoatings remelted by flame or by laser. // Wear. 262 (2007), pp. 301-307. DOI: 10.1016/j.wear.2006.05.009
[19] Bergant, Z; Trdan, U.; Grum, J. Effect of high-temperature furnace treatment on the microstructure and corrosion behaviour of NiCrBSi flame-sprayed coatings. // Corrosion Science. 88 (2014), pp. 372-386. DOI: 10.1016/j.corsci.2014.07.057

[20] Guoqing, C.; Xuesong, F.; Yanhui, W.; Shan, L.; Wenlong, Z. Microstructure and wear properties of nickel-based surfacing deposited by plasma transferred arc welding. // Surface \& Coatings Technology. 228 (2013), pp. 52765282. DOI: 10.1016/j.surfcoat.2012.05.125

[21] Liyanage, T.; Fisher, G.; Gerlich, A. P. Influence of alloy chemistry on microstructure and properties in $\mathrm{NiCrBSi}$ overlay coatings deposited by plasma transferred arc welding (PTAW). // Surface \& Coatings Technology. 205 (2010), pp. 759-765. DOI: 10.1016/j.surfcoat.2010.07.095

[22] Niranatlumpong, P.; Koiprasert, H. Phase transformation of $\mathrm{NiCrBSi}-\mathrm{WC}$ and NiBSi-WC arc sprayed coatings. // Surface \&Coatings Technology. 206 (2011), pp. 440-445. DOI: 10.1016/j.surfcoat.2011.07.057

[23] Simunovic, K.; Saric, T.; Simunovic, G. Different Approaches to the Investigation and Testing of the NiBased Self-Fluxing Alloy Coatings-A Review. Part 2: Microstructure, Adhesive Strength, Cracking Behavior, and Residual Stresses Investigations. // Tribology Transactions. 57 (2014), pp. 980-1000. DOI: 10.1080/10402004.2014.927548

[24] ASTM G65-94, Standard test method for measuring abrasion using the dry sand/rubber wheel apparatus. // in Annual Book of ASTM Standards, 3.02 (1995), pp. 232. DOI: $10.1520 / g 0065-04$

\section{Authors' addresses}

\section{Sara Havrlisan, Assistant}

J. J. Strossmayer University of Osijek,

Mechanical Engineering Faculty in Slavonski Brod, Trg I. Brlić-Mažuranić 2, 35000 Slavonski Brod, Republic of Croatia E-mail: sara.havrlisan@sfsb.hr

\section{Katica Simunovic, Full Professor}

J. J. Strossmayer University of Osijek, Mechanical Engineering Faculty in Slavonski Brod, Trg I. Brlić-Mažuranić 2, 35000 Slavonski Brod, Republic of Croatia

E-mail: katica.simunovic@sfsb.hr

\section{Djordje Vukelic, Associate Professor}

University of Novi Sad,

Faculty of Technical Sciences,

Trg Dositeja Obradovića 6, 21000 Novi Sad, Republic of Serbia

E-mail: vukelic@uns.ac.rs 